${ }^{1}$ Bazaral, M., and Helinski, D. R., J. Mol. Biol., 36, 185 (1968).

${ }^{2}$ Maggi, N., Pasqualucci, C., Ballotta, R., and Sensi, P., Chemotherapia, 11, 285 (1966).

${ }^{3}$ Hartmann, G., Honikel, K. O., Knüsel, F., and Nüesch, J., Biochim. Biophys. Acta, 145, 843 (1967).

${ }^{4}$ Umezawa, H., Mizuno, S., Yamazaki, H., and Nitta, K., J. Antibiotics, 21, 234 (1968).

${ }^{5}$ Wehrli, W., Nüesch, J., Knüsel, F., and Staehelin, M., Biochim. Biophys. Acta, 157, 215 (1968).

${ }^{6}$ Wilhelm, J., Oleinick, N., and Corcoran, J., Biochim. Biophys. Acta, 166, 268 (1968).

${ }^{7}$ Clowes, R., and Hayes, W., Experiments in Microbial Genetics, 187 (Wiley, New York, 1968).

${ }^{8}$ Clewell, D., and Helinski, D., Proc. US Nat. Acad. Sci., 62, 1159 (1969).

${ }^{9}$ Clewell, D., and Helinski, D., Biochemistry, 9, 4428 (1970).

10 Radloff, R., Bauer, W., and Vinograd, J., Proc. US Nat. Acad. Sci., 57, 1514 (1967).

${ }^{1 t}$ Wehrli, W., Knüsel, F., and Staehelin, M., Biochem. Biophys. Res. Commun., 32, 284 (1968).

12 Tocchini-Valentini, G., Marino, P., and Colvill, A., Nature, 220, 275 (1968).

${ }^{13}$ Ezekiel, D., and Hutchins, J., Nature, 220, 276 (1968).

${ }^{14}$ di Mauro, E., Snyder, L., Marino, P., Lamberti, A., Coppo, A., and Tocchini-Valentini, G., Nature, 222, 533 (1969).

${ }^{15}$ Lowry, O., Rosebrough, N., Farr, A., and Randall, R., J. Biol. Chem., 193, 265 (1951).

${ }^{16}$ Burgess, R., J. Biol. Chem., 244, 6160 (1969).

${ }_{17}$ Rabussay, D., and Zillig, W., FEBS Lett., 5, 104 (1969).

${ }^{18}$ Heil, A., and Zillig, W., FEBS Lett., 11, 165 (1970).

19 Burgess, R., Ann. Rev. of Biochem., 40,711 (1971).

${ }^{20}$ Kingsbury, D., and Helinski, D., Biochem. Biophys. Res. Commun., 41, 1538 (1970)

${ }^{21}$ Kornberg, A., Science, 163, 1410 (1969).

${ }^{22}$ Verma, I., Meuth, N., Bromfeld, E., Manly, K., and Baltimore, D., Nature New Biology, 233, 131 (1971).

${ }^{23}$ Sippel, A., and Hartmann, G., Biochim. Biophys. Acta, 157, 218 (1968).

${ }^{24}$ Brutlag, D., Schekman, R., and Kornberg, A., Proc. US Nat. Acad. Sci. (in the press).

${ }^{25}$ Lark, K. G., J. Mol. Biol. (in the press).

${ }^{26}$ Dove, W., Hargrove, E., Ohashi, M., Haugli, F., and Guha, A., Jap. J. Genet., 44, suppl. 1, 11 (1969).

${ }^{27}$ Dove, W., Inokuchi, H., and Stevens, W., in Bacteriophage Lambda (edit. by Hershey, A. D.), 747 (Cold Spring Harbor Lab. Quant. Biol., New York, 1971)

\section{Protein Polymorphism}

BULMER $^{1}$ has analysed data on multiple allelic series of genes determining enzymes, and has shown that if the alleles are arranged in order of electrophoretic mobility, there is a marked tendency for the rare alleles to occur at the beginning or the end of a sequence and for the common alleles to occur in the middle of a sequence.

This conclusion seems to be well justified by the data. But Bulmer goes on to argue that this finding is incompatible with the "neutral mutation" theory propounded by Kimura ${ }^{2}$ and others, according to which the majority of such polymorphisms are maintained by "genetic drift" of the frequencies of selectively neutral alleles in finite populations. This argument is false, because there are at least two processes which, if the neutral mutation theory is correct, would cause common alleles to occur at the middle of allclic series. (i) From time to time, a species will become genetically homogeneous at a locus. This will happen if the species passes through a bottleneck of numbers, or if a selectively favourable allele is established at or very close to the locus from a single original mutation. If selectively neutral variants subsequently arise at the locus and spread through the population, there will be a long period (of the order of $N$ generations, where $N$ is the effective population size) during which the original allele is the commonest allele at the locus. This original allele will be intermediate in charge if neutral mutations of higher and lower charge are possible. In any case it will be impossible during this long period for two common alleles to be separated by a rare allele of intermediate charge, and it is this pattern which Bulmer shows not to occur. (ii) If there are several sites in the protein at which selectively neutral substitutions involving a change in charge can occur, it will usually be impossible to distinguish electrophoretically between different alleles with the same total charge. These different alleles will therefore be classified as a single "allele" of intermediate charge. Suppose, for example, that there are two sites at which neutral substitutions are possible, each changing the total charge by one unit. Then there are four alleles-00, 01, 10, 11-but only three classes distinguishable by electrophoresis. We would expect the central class which includes two alleles to be commoner than the outside ones.

For these-reasons, the fact that the commonest alleles are often intermediate in charge is not evidence against the neutral mutation theory.

\section{J. Maynard Smith}

\section{School of Biological Sciences,} University of Sussex

Received December 24, 1971.

1 Bulmer, M. G., Nature, 234, 410 (1971).

2 Kimura, M., Nature, 217, 624 (1968).

\section{Iminoxyle Radical with Isocyanide as a Spin Label for Haemoproteins}

SPIN labelling has often been used to study conformational transitions in proteins ${ }^{1}$. Electron spin resonance (ESR) spectra of the iminoxyle radical attached to certain sites of a protein molecule indicate the spatial rearrangements of adjacent molecular groups ${ }^{1}$. We have synthesized a new spin label, which contains a isocyanide group and therefore specifically binds to iron-porphyrin moieties of haemoproteins. The iminoxyle radical with $-\mathrm{N}=\mathrm{C}$ group was prepared by reaction of chloroform with 2,2,6,6,-tetramethyl-4-aminopiperidyl-Noxyle in the presence of potassium hydroxide.

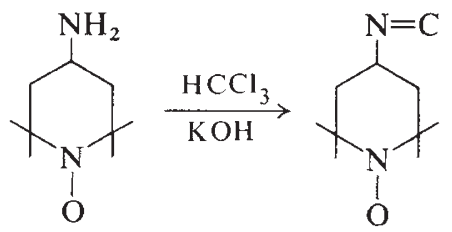

Dry benzene $(10 \mathrm{ml}$.) and $1 \mathrm{~g}$ of pulverized potassium hydroxide were boiled and then $1 \mathrm{~g}$ of 2,2,6,6-tetramethyl-4-aminopiperidyl-N-oxyle in $20 \mathrm{ml}$. of chloroform (free from ethanol) was added and the mixture was refluxed for $2 \mathrm{~h}$. The filtrate from this mixture was evaporated and chromatographed on aluminium oxide, using a mixture of chloroform : acetone $(3: 1 \mathrm{v} / \mathrm{v})$ as an eluent. The lower coloured zone was eluted and the solvents were evaporated from the eluate in vacuo. This gave about $100 \mathrm{mg}$ of bright yellow crystals with a melting point of $133^{\circ}-134^{\circ} \mathrm{C}$.

Isocyanide spin label (ISL) causes significant changes in the optical properties of haem-containing compounds to which it binds: the change in the optical spectrum of this system indicates the extent of ISL binding to haem. At the same time, the ESR spectrum of bound ISL gives information about the protein conformation near the haem. Therefore, ISL can be used not only with isolated haemoproteins but also for investigation of more complex systems.

Fig. 1, for example, shows an ISL-induced difference spectrum of rat liver microsomes. ISL causes the appearance of two peaks at 435 and $455 \mathrm{~nm}$, which are inherent to isocyanide derivatives of cytochrome $P_{450}$ (refs. 3 and 4 ) and proves that ISL is in fact bound to the cytochrome $P_{450}$ haem group. (Besides cytochrome $\mathrm{P}_{450}$, microsomes also contain cytochrome $\mathrm{b}_{5}$, but this does not interact with isocyanides ${ }^{3}$.) It is worth 